\title{
HUBUNGAN KEMANDIRIAN BELAJAR SISWA TERHADAP KEMAMPUAN PEMECAHAN MASALAH MATEMATIS SISWA
}

\author{
Ambiyar $^{1}$, Ishak Aziz ${ }^{2}$, Hafizah Delyana ${ }^{3}$ \\ ${ }^{1,2}$ Universitas Negeri Padang, J1. Prof Dr. Hamka, Padang, Sumatera Barat \\ ${ }^{3}$ STKIP PGRI Sumatera Barat, Jl. Gunung Panggilun, Padang, Sumatera Barat \\ ambiyar@ft.unp.ac.id
}

\begin{abstract}
The lack of independent learning and low problem-solving abilities are the background of this research. This study aims to determine the relationship between student learning independence and problem-solving abilities in class XI MIA 2 SMAN 1 Lubuk Basung. This research was conducted in the Odd Semester of 2020-2021. This research uses inferential research with quantitative analysis. This research is classified as a correlational research, which is to find out how the relationship between independent learning and students' problem solving abilities The sampling technique used purposive sampling. The data analysis technique used is simple linear regression analysis and Pearson correlation. Based on the regression coefficient data analysis, the questionnaire score (b) was 1.29 with a significant level of 0.05 . The regression coefficient (b) is positive, so there is a positive effect of $\mathrm{X}$ on $\mathrm{Y}$, meaning that the greater the $\mathrm{X}$ value the greater the $\mathrm{Y}$ value on average. The closeness of the linear relationship between $\mathrm{X}$ and $\mathrm{Y}$ is seen from the correlation coefficient $\mathrm{r}=0.78$, which means where $\mathrm{r}$ approaches 1, so that a strong linear relationship between $\mathrm{X}$ and $\mathrm{Y}$ is obtained. The conclusion is that independent learning has a positive relationship between independent learning and students' problem solving abilities.
\end{abstract}

Keywords: Independent Learning, Problem Solving Ability

\begin{abstract}
Abstrak
Kemandirian belajar yang masih kurang dan kemampuan pemecahan masalah yang masih rendah menjadi latar belakang penelitian ini. Penelitian ini bertujuan untuk mengetahui hubungan kemandirian belajar siswa dengan kemampuan pemecahan masalah di kelas XI MIA 2 SMAN 1 Lubuk Basung. Penelitian ini dilaksanakan pada Semester Ganjil Tahun 2020-2021. Penelitian ini menggunakan jenis penelitian inferensial dengan analisis kuantitatif. Penelitian ini tergolong penelitian korelasional yaitu untuk mengetahui bagaimana hubungan kemandirian belajar terhadap kemampuan pemecahan masalah siswa. Teknik pengambilan sampel menggunakan purposive sampling. Teknik analisis data yang digunakan adalah analisis regresi linear sederhana dan korelasi pearson. Berdasarkan analisis data koefisien regresi, skor angket (b) adalah 1,29 dengan tingkat signifikan sebesar 0,05. Koefisien regresi (b) bernilai positif maka ada pengaruh positif dari X terhadap Y, artinya semakin besar nilai X semakin besar pula nilai $\mathrm{Y}$ secara rata-rata. Keeratan hubungan linear antara $\mathrm{X}$ dan Y dilihat dari koefisien korelasi $r=0,78$ yang berarti dimana $r$ mendekati 1, sehingga didapatkan hubungan linear anatara $\mathrm{X}$ dan $\mathrm{Y}$ yang kuat. Kesimpulannya adalah kemandirian belajar hubungan yang positif antara kemandirian belajar dengan kemampuan pemecahan masalah siswa.
\end{abstract}

Kata Kunci: Kemandirian Belajar, Kemampuan Pemecahan Masalah

\section{PENDAHULUAN}

Menurut Hendriana dalam (Sriwahyuni, 2019) kemampuan pemahaman matematis merupakan suatu kekuatan yang harus diperhatikan selama proses pembelajaran matematika, terutama untuk memperoleh pengetahuan matematika yang bermakna. Mengingat pentingnya pemahaman matematis, maka siswa seharusnya dapat menguasai berbagai kemampuan matematis. Kemampuan pemecahan masalah matematis merupakan salah satu kemampuan yang harus dikuasai siswa , karena pemecahan 
masalah memberikan manfaat yang besar kepada siswa dalam melihat relevansi antara matematika dengan mata pelajaran yang lain serta dalam kehidupan nyata.

Kemampuan pemecahan masalah matematis merupakan kemampuan dimana siswa berupaya mencari jalan keluar yang dilakukan dalam mencapai tujuan, juga memerlukan kesiapan, kreativitas, pengetahuan dan kemampuan serta aplikasinya dalam kehidupan sehari-hari. Salah satu faktor yang mempengaruhi kemampuan pemecahan masalah siswa adalah kemandirian belajar. Kemandirian belajar merupakan suatu usaha yang dilakukan untuk melakukan aktivitas belajar dengan cara mandiri atas dasar motivasinya sendiri untuk menguasai suatu materi tertentu sehingga bisa dipakai untuk memecahkan masalah yang sedang dihadapi.(Asmar \& Delyana, 2020)

Pembelajaran mandiri merupakan proses mengendalikan diri untuk belajar tidak bergantung pada orang lain, mampu mengambil keputusan dan inisiatif untuk mengatasi masalah tanpa mengharapkan bantuan orang lain, dan memiliki rasa percaya diri dalam melaksanakan tugas. Kemampuan siswa akan dipengaruh oleh kemandiriannya dalam belajar. Hal ini sesuai dengan (Novantri \& Aftriyati, 2020) yang menyatakan bahwa terdapat perbedaan hasil belajar matematika antara siswa yang memiliki Kemandirian belajar tinggi, sedang dan rendah. kemandirian belajar siswa masih rendah akibat kurangnya kesadaran diri dalam hal belajar, (Apriani et al., 2017). Selanjutnya, (Asworowati, 2020) juga berpendapat bahwa semakin tinggi kemandirian siswa, maka akan semakin tinggi pula hasil belajar matematika siswa. Begitu pun sebaliknya, semakin rendah kemandirian siswa, maka akan semakin rendah pula hasil belajar matematika siswa. Hal ini sejalan dengan Penelitian (Sulistyani \& Roza, 2020) yang menyatakan bahwa kemandirian belajar dapat dijadikan sebagai salah satu faktor yang dapat mempengaruhi kemampuan pemecahan masalah matematis peserta didik. Jika kemandirian belajar yang dimiliki peserta didik tinggi, maka kemampuan pemecahan masalah peserta didik baik, namun jika kemandirian belajar peserta didik rendah, maka kemampuan pemecahan masalah kurang baik.

Observasi yang dilaksanakan dari tanggal 27 Januari 2020 sampai tanggal 3 Februari tahun 2020 di SMAN 1 Lubuk Basung, pada proses pembelajaran matematika terlihat bahwa siswa cenderung menerima penjelasan dari guru saja tanpa mau mencari sumber lainnya. Di saat guru memberikan contoh soal, dan selanjutnya guru menanyakan pemahaman siswa terhadap contoh tersebut, akan tetapi jika guru memberikan bentuk latihan soal yang berbeda tingkat kesulitannya dari contoh soal, siswa mulai kebingungan untuk menyelesaikan soal tersebut karena siswa terpaku dengan cara penyelesaian guru. Siswa tidak terbiasa menyelesaikan permasalahan non rutin yang mengakibatkan tidak terjadinya peningkatan kemampuan pemecahan masalah. Selain itu siswa kurang berinisiatif untuk mempelajari sendiri pelajaran yang akan dipelajari, padahal jika siswa mempunyai kesadaran untuk belajar mandiri akan lebih mudah menerima informasi yang disampaikan oleh guru, tetapi hal ini tidak dilakukan oleh kebanyakan siswa. Kemapuan pemecahan masalah merupakan kemampuan yang diperlukan dalam belajar dan matematika itu sendiri. Oleh karena itu pemecahan masalah matematika merupakan hal yang sangat penting dalam pembelajaran matematika karena 
Hubungan Kemandirian Belajar Siswa Terhadap Kemampuan Pemecahan Masalah Matematis Siswa, Ambiyar, Ishak

dapat mempermudah siswa dalam menghadapi masalah-masalah dalam kehidupan siswa pada hari ini dan pada hari yang akan datang. (Akbar et al., 2017)

Wawancara yang dilakukan dengan guru matematika di sekolah ini diperoleh informasi bahwa dalam proses pembelajaran pada saat guru memberikan contoh soal, terlihat siswa sudah paham. Namun pada saat diberi latihan yang lebih sulit dari contoh soal, siswa mulai kebingungan menyelesaikan latihan tersebut. Hal ini menyatakan bahwa siswa kurang maksimal dan masih mengalami kesulitan dalam memecahkan masalah yang diberikan. Ketika siswa diberikan soal yang memuat indikator kemampuan pemecahan masalah siswa tidak mampu menyelesaikannya dengan benar.

Ketidakmampuan siswa dalam menyelesaikan soal pemecahan masalah disebabkan oleh banyak faktor. Masih banyak siswa yang tidak yakin pada kemampuan diri sendiri, siswa kurang berusaha mengerjakan latihan sendiri, hanya menyalin jawaban dari temannya. Kurangnya kemauan untuk belajar mandiri dan dalam pembelajaran siswa jarang sekali diajak untuk menganalisis suatu permasalahan sehingga menemukan sendiri solusinya. Siswa sering terkendala dalam menyelesaikan soal uraian. Hal ini senada dengan pendapat (Marfungah et al., 2020) yang menyatakan bahwa ketika siswa diminta untuk menyelesaikan soal uraian biasanya siswa cenderung hanya mensubtitusi nilai suatu rumus tertentu tanpa mengelaborasi pengetahuannya untuk memecahkan masalah.

Hasil wawancara dengan beberapa orang siswa kelas X MIA SMAN 1 Lubuk Basung diperoleh informasi bahwa siswa terbiasa menunggu bantuan temannya ketika mengalami kesulitan belajar matematika, tidak mengulangi materi yang belum dikuasai, dan siswa mudah menyerah dalam menyelesaikan soal non rutin. Hal ini terlihat bahwa kurangnya kemandirian belajar siswa. Kemandirian belajar sangat berpengaruh pada keadaan sekarang, Pandemi covid-19 yang terjadi mengharuskan siswa belajar dirumah, dengan menerapkan pembelajaran secara daring, yaitu pembelajaran yang didukung oleh pengguna alat atau konten digital. Pembelajaran daring dilakukan sejak tanggal 3 april 2020 sampai akhir semester genap. Menteri Pendidikan dan Kebudayaan (Mendikbud) Nadiem Makarim mengatakan, "Prinsip dikeluarkannya kebijakan pendidikan di masa pandemi covid-19 adalah dengan memprioritaskan kesehatan dan keselamatan peserta didik, pendidik, tenaga kependidikan, keluarga, dan masyarakat. Tahun ajaran baru bagi satuan pendidikan ditahun ajaran 2020/2021 khususnya di provinsi Sumatera barat tetap dimulai pada bulan Juli 2020. Namun demikian, untuk daerah yang berada di zona kuning, oranye, dan merah, tetap melanjutkan belajar dari rumah. Hal ini diberitahukan oleh Gubernur Sumatera Barat sesuai dengan Surat Edaran Sekjen Kemendikbud Nomor 15 Tahun 2020 tentang Pedoman Penyelenggaraan Belajar dari Rumah dalam Masa Darurat Penyebaran Covid-19. Isi surat edaran ini selain tentang pedoman pelaksanaan belajar dari rumah, juga terkait panduan kegiatan pembelajaran saat satuan pendidikan kembali beroperasi. Jadi dengan adanya kemandirian belajar dalam diri siswa, sehingga siswa sudah terbiasa belajar mandiri dari rumah. 
Berdasarkan uraian permasalahan di atas, maka peneliti tertarik untuk melihat hubungan kemandirian belajar siswa dengan kemampuan pemecahan masalah matematis siswa pada materi program linier di SMA Kelas XI.

\section{METODE}

Jenis penelitian ini adalah jenis penelitian inferensial dengan analisis kuantitatif. Penelitian ini tergolong penelitian korelasional yaitu untuk mengetahui mengetahui bagaimana hubungan kemandirian belajar terhadap kemampuan pemecahan masalah matematis siswa di masa pendemi covid 19. Penelitian ini dilaksanakan pada semester Ganjil tahun pelajaran 2020/2021 di kelas XI MIA 2 SMAN 1 Lubuk Basung Kabupaten Agam. Subjek penelitian dipilih secara purposive sampling. Menurut Sugiyono (2013) dalam (Singestecia, 2018) "purposive sampling adalah teknik penentuan sampel dengan pertimbangan tertentu". Berdasarkan pertimbangan yang dilakukan dalam pemilihan subjek dan saran guru bidang studi, subjek pada penelitian ini adalah siswa kelas XI MIA 2 SMAN 1 Lubuk Basung. Berikut alur pelaksanaan penelitian yang dilakukan:

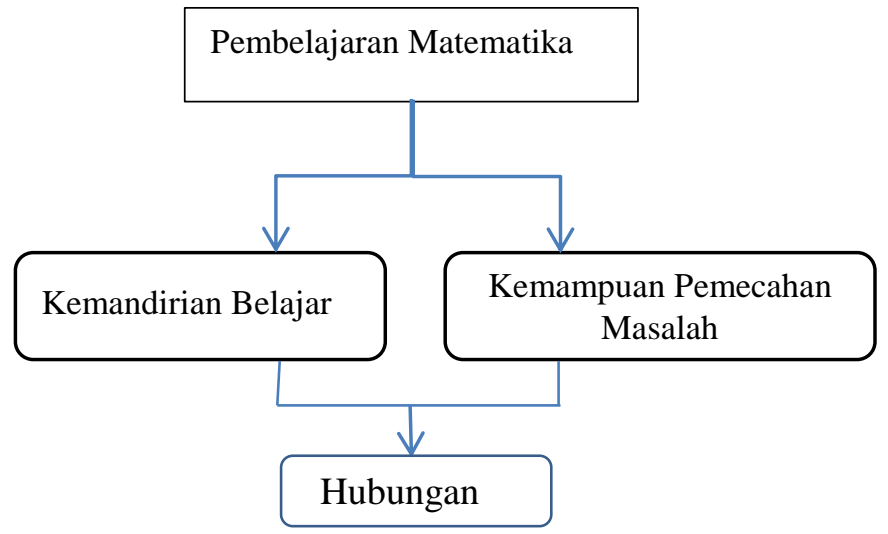

Gambar 1. Bagan Alir Penelitian

Instrumen yang digunakan pada penelitian ini adalah angket kemandirian belajar dan tes kemampuan pemecahan masalah matematis. Angket yang digunakan pada penelitian ini adalah angket baku kemandirian belajar menurut Hendriana (2017) dalam (Sriwahyuni, 2019). Angket kemandirian belajar ini telah disusun berdasarkan indikator-indikator kemandirian belajar, dan ada beberapa pernyataan yang harus disesuaikan dengan kondisi dan situasi pembelajaran secara daring. Pernyataan terdiri dari pernyataan positif dan negatif. Angket yang digunakan adalah angket baku yang bersifat tertutup.

Selanjutnya tes kemampuan pemecahan masalah matematis berbentuk essay dengan jumlah soal sebanyak 4 soal. Berikut contoh soal pemecahan masalah yang diberikan kepada siswa:

Luas daerah parkir $360 \mathrm{~m}^{2}$. Luas rata-rata sebuah mobil $6 \mathrm{~m}^{2}$ dan luas rata-rata bus $24 \mathrm{~m}^{2}$. Daerah parkir terebut dapat memuat paling banyak 30 kendaraan roda empat (mobil dan bus). Jika tarif parkir mobil Rp 2.000 dan tarif bus $R p$ 5.000, maka tentukanlah pendapatan terbesar yang dapat diperoleh! 
Hubungan Kemandirian Belajar Siswa Terhadap Kemampuan Pemecahan Masalah Matematis Siswa, Ambiyar, Ishak Aziz, Hafizah Delyana

Selanjutnya, hasil dari tes pengisian angket dan tes akhir akan dianalisis dan disimpulkan, maka akan diperoleh deskripsi tentang kemandirian belajar terhadap kemampuan pemecahan masalah matematis siswa. Pada tahap analisis data dilakukan dengan analisis skor angket kemandirian belajar yang dilakukan dengan menentukan jumlah skor yang diperoleh masing-masing siswa terlebih dahulu. Jumlah skor yang diperoleh kemudian dibagi dengan jumlah skor maksimum angket dan dikali dengan $100 \%$ untuk mendapatkan persentase skor kemandirian belajar dapat dirumuskan, (Asmar \& Delyana, 2020) :

$$
\text { Skor }=\frac{\text { skor yang diperoleh siswa }}{\text { skor maksimum }} \times 100 \%
$$

Teknik analisis data selanjutnya adalah analisis data untuk melihat pengaruh kemandirian belajar terhadap kemampuan pemecahan masalah siswa. Hipotesis diuji dengan menggunakan analisis regresi linier sederhana. Regresi linier sederhana didasarkan pada hubungan fungsional ataupun kausal antara satu variabel independen dengan satu variabel dependen. Menurut (Hijriani et al., 2016) persamaan umum regresi linier sederhana adalah:

$$
\begin{aligned}
& Y=a+b X \\
& a=\frac{\sum X^{2} \sum Y-\sum X \sum X Y}{n \sum X^{2}-\left(\sum X\right)^{2}} \\
& b=\frac{n \sum X Y-\sum X \sum Y}{n \sum X^{2}-\left(\sum X\right)^{2}}
\end{aligned}
$$

Keterangan:

$Y \quad=$ Tes kemampuan pemecahan masalah

$a \quad=$ harga $Y$ bila $X=0$ (harga konstan)

$b \quad=$ angka arah atau koefisien regresi, yang menunjukan angka peningkatan atau penurunan variabel dependen yang didasarkan pada variabel independen. Bila $b(+)$ maka naik, bila $b$ (-) maka terjadi penurunan

$X \quad=$ skor angket kemandirian

Keeratan hubungan linier antara $X$ dan $Y$ dapat dilihat dari koefisien korelasi. Rumus koefisien korelasi Produt Moment dari Pearson sebagai berikut.

$$
r=\frac{n \sum X Y-\sum X \sum Y}{\sqrt{n \sum X^{2}-\left(\sum X\right)^{2}} \sqrt{n \sum Y^{2}-\left(\sum Y\right)^{2}}}
$$

Nilai koefisien korelasi sampel $r$ berkisar antara -1 sampai 1. Jika $r=0$, maka tidak ada hubungan linier antara variabel $X$ dan Y. jika $r$ mendekati 0 , maka hubungan linier antara $X$ dan $Y$ 
lemah. Semakin dekat nilai $r$ dengan 1 atau -1 semakin kuat hubungan linier antara $X$ dan $Y$. jika $r=1$ atau $r=-1$, maka semua sampel berada pada garis regresi. Nilai $r$ yang positif menunjukan adanya hubungan linier positif antara $X$ dan $Y$, dalam arti semakin besar $X$ semakin besar pula $Y$. Nilai $r$ yang negatif menunjukan adanya hubungan linier negatif antara $X$ dan $Y$, dalam arti semakin besar $X$ maka nilai $Y$ semakin kecil.

\section{HASIL}

Kemandirian belajar siswa di dalam proses pembelajaran matematika dilihat dari angket kemandirian yang dibagikan pada kelas XI MIA 2 SMAN 1 Lubuk Basung Kabupaten Agam dengan jumlah responden 30 orang siswa. Tingkat kemandirian belajar siswa dapat dilihat dari persentase perindikator yang terdapat pada Tabel 1.

\section{Tabel 1.}

Persentase Kemandirian Belajar Perindikator

\begin{tabular}{|l|l|l|}
\hline NO & Indikator & Skor (\%) perindikator \\
\hline 1 & Inisiatif dan motivasi belajar instrinsik & 65,56 \\
\hline 2 & Mendiagnosa kebutuhan belajar & 65,00 \\
\hline 3 & Menetapkan tujuan/target belajar & 68,61 \\
\hline 4 & Memilih, menetapkan strategi belajar & 72,08 \\
\hline 5 & Memonitor, mengatur, dan mengontrol belajar & 66,67 \\
\hline 6 & Memandang kesulitan sebagai tantangan & 65,42 \\
\hline 7 & Memanfaatkan dan mencari sumber yang relevan & 70,00 \\
\hline 8 & Mengevaluasi proses dan hasil belajar & 74,72 \\
\hline 9 & Sel-Efficacy (konsep diri) & 65,83 \\
\hline
\end{tabular}

Pada Tabel 1, terlihat bahwa persentase kemandirian belajar perindikator berada diantara $60 \%$ dan $75 \%$ maka kemandirian belajar siswa dapat dikategorikan baik. Persentase indikator tertinggi adalah mengevaluasi proses dan hasil belajar dengan persentase $74,72 \%$. Persentase indikator terendah adalah mendiagnosa kebutuhan belajar dengan persentase $65,00 \%$.

Data tes kemampuan pemecahan masalah diambil dari hasil tes yang telah dilakukan siswa. Berdasarkan perhitungan didapat nilai rata-rata $(\underline{x})$, skor tertinggi $\left(x_{\max }\right)$ adalah 94 , skor terendah $\left(x_{\min }\right)$ adalah 30 . Berdasarkan data yang diperoleh dari skor angket dan skor tes kemampuan pemecahan masalah yang telah dilakukan, analisis yang dilakukan menggunakan analisis regresi linear sederhana, dapat dilihat pada Tabel 2.

\section{Tabel 2.}

Hasil Analisis Regresi Linear Sederhana

\begin{tabular}{|c|c|c|c|c|}
\hline $\begin{array}{l}\text { Variabel } \\
\text { Terikat }\end{array}$ & Variabel Bebas & $\begin{array}{l}\text { Koefisien } \\
\text { Regresi }\end{array}$ & $\mathbf{T}$ & Sig \\
\hline \multirow{2}{*}{$\begin{array}{l}\text { Tes } \\
\text { kemampuan } \\
\text { pemecahan } \\
\text { masalah }(Y)\end{array}$} & Konstanta & $-29,93$ & \multirow[b]{2}{*}{6,61} & \multirow[b]{2}{*}{0,05} \\
\hline & Skor angket $(X)$ & 1,29 & & \\
\hline
\end{tabular}


Hubungan Kemandirian Belajar Siswa Terhadap Kemampuan Pemecahan Masalah Matematis Siswa, Ambiyar, Ishak Aziz, Hafizah Delyana

Tabel 2 skor angket $(\mathrm{X})$ dan tes kemampuan pemecahan masalah (Y) dapat dinyatakan dalam persamaan regresi linear sederhana sebagai berikut:

$$
\begin{gathered}
Y=a+b X \\
Y=-29,93+1,290 X
\end{gathered}
$$

Persamaan regresi linear sederhana di atas dapat diartikan bahwa nilai koefisien regresi skor angket akhir $(b)$ adalah 1,29 dengan tingkat signifikansi sebesar 0,05 karena koefisien regresi (b) bernilai positif (+), maka ada pengaruh positif dari $X$ terhadap $Y$. Artinya, semakin besar $X$ semakin besar pula $Y$ secara rata-rata. Hal itu dapat dilihat pada Gambar 1.

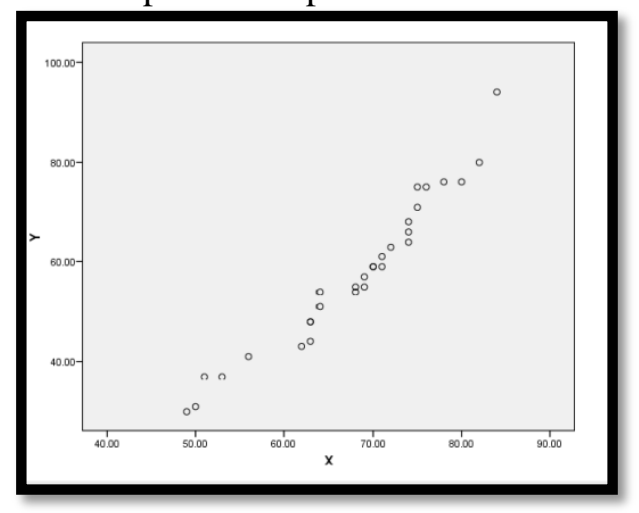

Gambar 2. Grafik Hasil Analisis Regresi

Gambar 2, terlihat bahwa $b>0$ sehingga grafik naik. Akibatnya, setiap kenaikan satu satuan dalam $X$ akan memberikan kenaikan positif sebesar $b$ pada $Y$. Berdasarkan analisis nilai korelasi pearson diperoleh nilai koefiien korelasi $r=0,78$ yang berarti bahwa $r$ mendekati 1 , maka hubungan linier antara $X$ dan $Y$ kuat. Tingkat signifikansi sebesar 0,05 yang berarti bahwa korelasi antara variabel $X$ dan $Y$ signifikan.

Selanjutnya dilakukan uji signifikansi koefisien dengan menggunakan uji statistik (Suyono, 2015) diperoleh hasil perhitungan $t_{\text {hitung }}=6,61$. Hasil yang diperoleh dibandingkan dengan nilai distribusi t pada $\alpha=0,05$ dengan derajat bebas $n-2$ diperoleh nilai $t_{\text {tabel }}=1,70$ Karena $t_{\text {hitung }}>t_{\text {tabel }}$ maka $H_{0}$ ditolak, sehingga terdapat korelasi yang signifikan antara $X \operatorname{dan} Y$. Dengan demikian dapat diartikan bahwa kemandirian belajar berpengaruh positif terhadap tes kemampuan pemecahan masalah dan signifikan. Hal ini juga didukung oleh hasil penelitian (Mayasari, 2019)yang menemukan bahwa terdapat hubungan yang linear antara kemandirian belajar dengan kemampuan pemecahan masalah matematis siswa. Hal ini juga sejalan dengan (Mulyono, 2017) yang menyatakan bahwa Kemandirian belajar merupakan persepsi atau pandangan seseorang terhadap dirinya sendiri yang dibentuk melalui pengalaman dan interaksi dengan lingkungan serta dipengaruhi oleh orangorang yang dianggap penting, dengan meningkatkan kemandirian belajar siswa maka kemandirian belajar akan semakin baik. akan berdampak pada kemampuan dan hasil belajar begitu pula sebaliknya. 
Penelitian ini dilakukan untuk mengetahui hubungan kemandirian belajar siswa dengan kemampuan pemecahan masalah pada kelas XI MIA 2 SMA N 1 Lubuk Basung Kabupaten Agam. Peneliti memberikan angket kemandirian belajar sebelum memberikan soal tes kemampuan pemecahan masalah. Soal tes kemampuan pemecahan masalah berupa soal uraian sebanyak 4 butir dengan materi program linear.

Kriteria penilaian kemampuan pemecahan masalah siswa dalam lima kategori yaitu kategori sangat rendah, rendah, sedang, tinggi, dan sangat tinggi. Pada penelitian ini, kategori yang terpenuhi dari 30 responden yang diteliti hanya kategori sangat tinggi, tinggi, sedang, dan rendah. 4 orang kategori rendah, 14 orang kategori sedang, 11 orang kategori tinggi, dan 1 orang kategori sangat tinggi. Berdasarkan kriteria penilaian kemandirian belajar, diperoleh 2 orang memiliki kemandirian belajar dalam kategori lemah, 23 orang memiliki kemandirian belajar dalam kategori kuat, dan 5 orang memiliki kemandirian belajar dalam kategori sangat kuat. Kategori tersebut dapat dilihat pada Tabel 3:

Tabel 3.

Kategori Siswa Berdasarkan Kriteria Penilaian Kemandirian Belajar dan Kemampuan Pemecahan Masalah

\begin{tabular}{|c|c|c|c|c|c|}
\hline \multicolumn{2}{|c|}{ Jumlah Siswa (Orang) } & \multicolumn{4}{|c|}{ Hasil Tes Kemampuan Pemecahan Masalah } \\
\hline \multirow{4}{*}{$\begin{array}{l}\text { Hasil } \\
\text { Angket } \\
\text { Kemandirian } \\
\text { Belajar }\end{array}$} & & Sangat tinggi & Tinggi & Sedang & Rendah \\
\hline & Sangat Kuat & 1 & 4 & - & - \\
\hline & Kuat & - & 7 & 14 & 2 \\
\hline & Lemah & - & - & - & 2 \\
\hline
\end{tabular}

Berdasarkan kriteria penilaian kemandirian belajar dan kemampuan pemecahan masalah, 30 siswa dapat digolongkan ke dalam kriteria seperti yang terlihat pada Tabel 3. Perhatikan beberapa uraian dari masing-masing kriteria berikut:

\section{Siswa dengan Kemampuan Pemecahan Masalah Tinggi dan Kemandirian Belajar Sangat Kuat}

Pada Tabel 3 dapat dilihat bahwa terdapat 4 orang siswa dengan kemampuan pemecahan masalah tinggi dan kemandirian belajar sangat kuat. Berikut contoh jawaban siswa dengan kriteria tersebut. Pada soal no 3" Luas daerah parkir $360 \mathrm{~m}^{2}$. Luas rata-rata sebuah mobil $6 \mathrm{~m}^{2}$ dan luas rata-rata bus $24 \mathrm{~m}^{2}$. Daerah parkir terebut dapat memuat paling banyak 30 kendaraan roda empat (mobil dan bus). Jika tarif parkir mobil $\mathrm{Rp} 2.000$ dan tarif bus $\mathrm{Rp}$ 5.000, maka tentukanlah pendapatan terbesar yang dapat diperoleh!". 


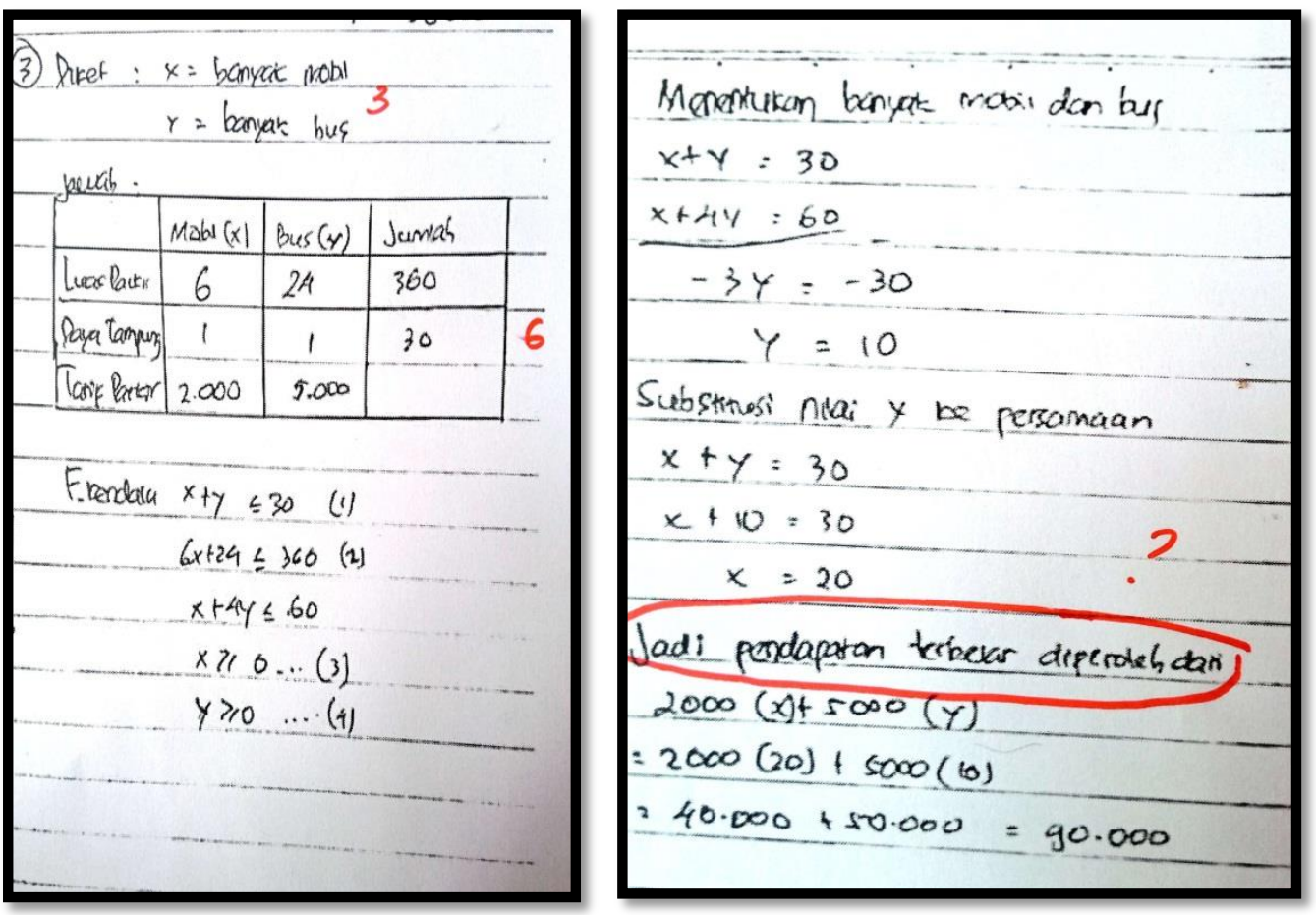

Gambar 3. Jawaban Siswa dengan Kemampuan Pemecahan Masalah Tinggi dan Kemandirian Belajar Sangat Kuat

Jawaban siswa dengan kemampuan pemecahan masalah tinggi memiliki kemandirian belajar sangat kuat pada soal nomor 3. Diamati dari jawaban siswa tersebut pada indikator memahami masalah siswa mampu memaparkan masalah dengan baik. Pada indikator merencanakannya pemecahannya siswa mampu membuatkan informasi soal dalam bentuk tabel. Pada indikator menyelesaikan masalah, siswa kurang mampu menyelesaikannya dengan benar, tidak menyelesaikannya secara secara bertahap, siswa tidak membuatkan gambar daerah penyelesaian yang digunakan untuk menentukan titik uji sudut. Siswa langsung saja menggunakan titik potong dari hasil eliminasi dan subsitusi persamaan yang diketahui. Sehingga siswa salah dalam memperoleh pendapatan terbesar. Hal ini juga ditemukan oleh (Listanti et al., 2020) dalam penelitiannya yaitu siswa berkemampuan matematika tinggi mengerjakan soal secara langsung tanpa menuliskan apa yang ia pahami seperti hal yang diketahui dan ditanyakan dalam soal. Pada tahap memahami masalah, siswa diharapkan dapat menyatakan apa yang dia pahami dari masalah tersebut dan menentukan apa yang diberikan dan tidak diketahui dalam masalah tersebut serta dapat menyarankan secara jelas kondisi masalah tersebut. Pada tahap menentukan strategi, siswa diharapkan dapat menentukan langkah-langkah seperti menghitung, menggambar, dan lain-lain. (Ersoy, 2016)

\section{Siswa dengan Kemampuan Pemecahan Masalah Rendah dan Kemandirian Belajar Lemah}

Pada Tabel 3 dilihat bahwa siswa dengan kemampuan pemecahan masalah rendah memiliki kemandirian belajar lemah berjumlah 2 orang siswa. Berikut contoh jawaban siswa dengan kriteria tersebut. Pada soal nomor 1" Untuk membuat barang tipe A, diperlukan 4 jam kerja mesin I dan 2 jam kerja mesin II. Untuk membuat barang tipe B, diperlukan 5 jam kerja mesin I dan 3 jam kerja mesin 
II. Setiap hari masing-masing mesin tersebut bekerja tidak lebih dari 15 jam dan dapat dihasilkan $x$ barang tipe A dan y barang tipe B. Buatlah model matematika dari permasalahan di atas!”.

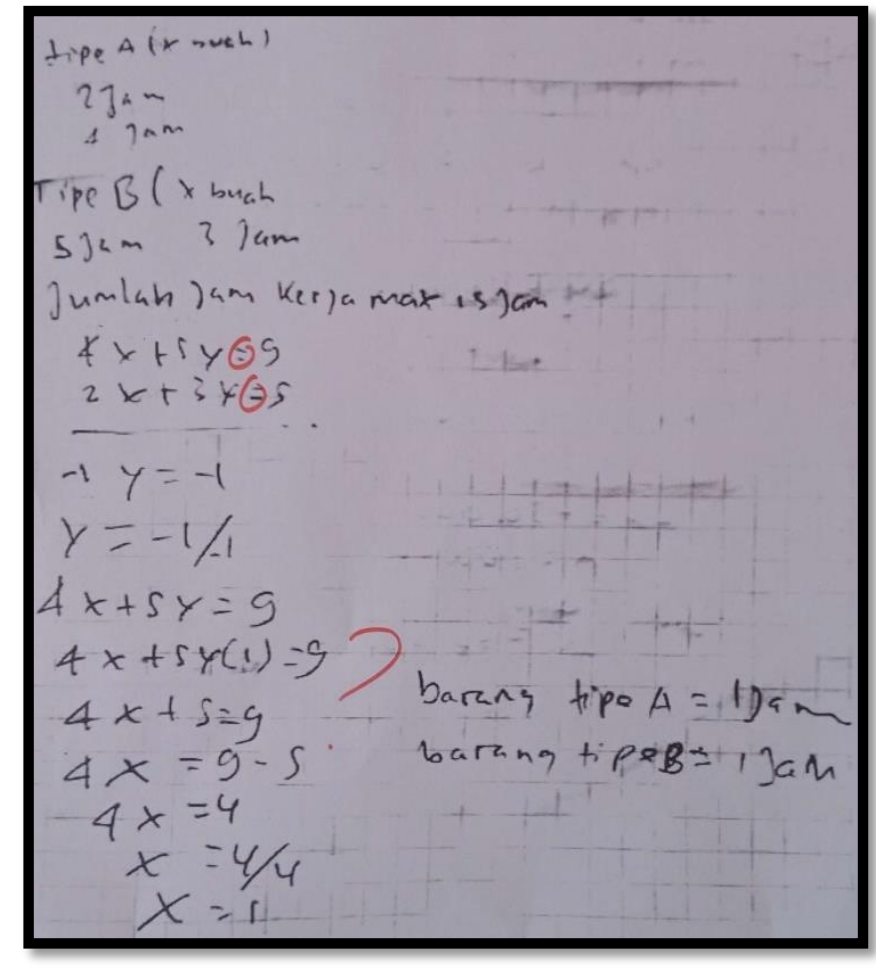

Gambar 4. Jawaban Siswa dengan Kemampuan Pemecahan Masalah Rendah dan Kemandirian Belajar Lemah

Jawaban siswa dengan kemampuan pemecahan masalah rendah memiliki kemandirian belajar lemah. Berdasarkan penyelesaian siswa pada soal nomor 1 tersebut, terlihat bahwa siswa belum mampu membuat unsur-unsur yang diketahui dan ditanya. Hal ini menunjukkan dari 4 indikator yang terdapat pada kemampuan pemecahan masalah hanya indikator memahami masalah saja yang dapat dipenuhi oleh siswa, pada indikator merencanakan pemecahannya siswa tidak mampu membuat sistem persamaan dari permasalahan, sehingga siswa juga tidak memenuhi indikator menyelesaikan masalah sesuai rencana dan pengecekan kembali tidak ada. Salah satu alasan hal ini terjadi adalah karena siswa tidak mampu memahami maksud dari soal. Tahap memahami masalah adalah tahap penting dalam menyelesaikan suatu masalah, bila siswa tidak dapat memahami permasalahan yang ada, siswa tidak dapat menyelesaikan masalah dengan tepat, (Wakit \& Hadapiningradja, 2018). Hal ini senada dengan penemuan (Akbar et al., 2017) yaitu siswa tidak dapat menterjemahkan soal kedalam kalimatnya sendiri. Sedangkan kesalahan dalam memeriksa kembali solusi yang diperoleh, disebabkan karena siswa beranggapan bahwa siswa merasa tidak perlu dalam melakukan pengecekan karena dia yakin bahwa jawaban yang diberikan sudah benar. Di samping itu (Delyana, 2015) juga menyatakan bahwa siswa tersebut sudah mampu memahami masalah dengan baik, namun belum mampu memilih strategi yang cocok untuk menyelesaikan soal tersebut. Sehingga, (Febriana et al., 2020) menyatakan jawaban siswa yang memiliki kemampuan 
Hubungan Kemandirian Belajar Siswa Terhadap Kemampuan Pemecahan Masalah Matematis Siswa, Ambiyar, Ishak

pemecahan masalah berada pada kategori baik dimana mahasiswa tersebut sudah mampu memahami masalah, membuat rencana penyelesaian soal, dan memeriksa ulang jawaban.

Berdasarkan pembahasan yang diuraikan di atas, diketahui siswa merencanakan pemecahan masalah dengan menggunakan konsep yang sesuai dengan permasalahan dan dapat memilih data yang diperlukan. Hal ini juga didukung oleh hasil penelitian (Listanti et al., 2020) yang menemukan bahwa siswa merencanakan pemecahan masalah menggunakan konsep yang sama untuk menyelesaikan masalah tertentu, namun siswa berkemampuan matematika sedang dan rendah melakukan kesalahan dalam mengidentifikasi data yang diperlukan sehingga merencanakan pemecahan masalah dengan pemahaman yang tidak sesuai kaidah, (Listanti et al., 2020). Siswa beranggapan bahwa menuliskan rencana penyelesaian soal merupakan suatu pekerjaan yang sangat berat. Sebagian besar siswa tidak pernah merencanakan penyelesaian soal, (Delyana, 2015).

\section{KESIMPULAN}

Berdasarkan perolehan skor angket kemandirian belajar dan skor tes kemampuan pemecahan masalah matematis siswa diketahui bahwa skor angket kemandirian siswa sebesar 67,93 dan rata-rata hasil tes kemampuan pemecahan masalah siswa sebesar 57,70 artinya semakin besar kemandirian belajar siswa maka kemampuan pemecahan masalah matematis siswa semakin juga semakin baik. Berdasarkan analisis hasil penelitian yang diperoleh, maka dapat disimpulkan bahwa terdapat pengaruh kemandirian belajar terhadap kemampuan pemecahan maalah mtematis siswa di kelas XI MIA 2 SMAN 1 Lubuk Basung.

\section{DAFTAR PUSTAKA}

Akbar, P., Hamid, A., Bernard, M., \& Sugandi, A. I. (2017). Analisis Kemampuan Pemecahan Masalah Dan Disposisi Matematik Siswa Kelas Xi Sma Putra Juang Dalam Materi Peluang. Jurnal Cendekia: Jurnal Pendidikan Matematika, 2(1), 144-153. https://doi.org/10.31004/cendekia.v2i1.62

Apriani, N., Khasanah, U., Studi, P., Matematika, P., Ahmad, U., Ring, J., Selatan, R., \& Yogyakarta, B. (2017). The Relationships Among Learning Independence, Reasoning Ability, And Learning Environment At Home With Students Mathematics Learning Outcomes In Class Xi Tkj Of Even Semester In Smk Negeri 1 Pleret Bantul. AdMathEduSt ISSN 2355-8199, 4(2), $111-114$.

Asmar, A., \& Delyana, H. (2020). Hubungan Kemandirian Belajar Terhadap Kemampuan Berpikir Kritis Melalui Penggunaan Software Geogebra. AKSIOMA: Jurnal Program Studi Pendidikan Matematika, 9(2), 221-230. https://doi.org/10.24127/ajpm.v9i2.2758

Asworowati, M. T. (2020). Hubungan Kemandirian Belajar dengan Hasil Belajar Matematika Siswa 
Kelas V SDN Se-Kecamatan Grabag Tahun Ajaran 2019/2020. Kalam Cendekia: Jurnal Ilmiah Kependidikan, 8(1), 77-82.

Delyana, H. (2015). PENINGKATAN KEMAMPUAN PEMECAHAN MASALAH MATEMATIKA SISWA KELAS VII MELALUI PENERAPAN. Lemma, II(1), 26-34.

Ersoy, E. (2016). Problem Solving and Its Teaching in Mathematics. The Online Journal of New Horizons in Education, 6(2), 79-87.

Febriana, R., Yusri, R., \& Delyana, H. (2020). Modul Geometri Ruang Berbasis Problem Based Learning Terhadap Kreativitas Pemecahan Masalah. AKSIOMA: Jurnal Program Studi Pendidikan Matematika, 9(1), 93. https://doi.org/10.24127/ajpm.v9i1.2591

Hijriani, A., Muludi, K., \& Andini, E. A. (2016). Implementasi Metode Regresi Linier Sederhana Pada Penyajian Hasil Prediksi Pemakaian Air Bersih Pdam Way Rilau Kota Bandar Lampung Dengan Sistem Informasi Geofrafis. Informatika Mulawarman: Jurnal Ilmiah Ilmu Komputer, 11(2), 37. https://doi.org/10.30872/jim.v11i2.212

Listanti, D. R., Mampouw, H. L., Kristen, U., \& Wacana, S. (2020). Profil pemecahan masalah geometri oleh siswa smp ditinjau dari perbedaan kemampuan matematika. Jurnal Cendekia: Jurnal Pendidikan Matematika, 04(01), 365-379.

Marfungah, A., Nugraheni, P., \& Yuzianah, D. (2020). P Pengaruh Model Pembelajaran Cooperative Script dan Circ Dalam Kemampuan Pemecahan Masalah Ditinjau Dari Gaya Kognitif. Jurnal Cendekia: Jurnal Pendidikan Matematika, 4(2), 779-786. https://doi.org/10.31004/cendekia.v4i2.288

Mayasari. (2019). Pengaruh Kemandirian Belajar terhadap Kemampuan Pemecahan Masalah Matematis Siswa SMP. Jurnal Cendekia: Jurnal Pendidikan Matematika, 3(1), 82-88. https://doi.org/10.31331/medivesveteran.v3i1.646

Mulyono, D. (2017). The influence of learning model and learning independence on mathematics learning outcomes by controlling students , early ability. International Electronic Journal of Mathematics Education, 12(3), 689-708.

Novantri, W., \& Aftriyati, L. W. (2020). ARE DISCOVERY LEARNING AND INDEPENDENT LEARNING EFFECTIVE IN IMPROVING STUDENTS' COGNITIVE SKILLS ? BELAJAR EFEKTIF DALAM MENINGKATKAN KEMAMPUAN. Indonesian Journal of Science and Mathematics Education, 03(July), 144-152. https://doi.org/10.24042/ijsme.v3i2.6615

Singestecia, R. (2018). Partisipasi Politik Masyarakat Tionghoa dalam Pemilihan Kepala Daerah di 
Hubungan Kemandirian Belajar Siswa Terhadap Kemampuan Pemecahan Masalah Matematis Siswa, Ambiyar, Ishak Aziz, Hafizah Delyana

Slawi Kabupaten Tegal. Unnes Political Science Journal, 2(1), 63-72.

Sriwahyuni, T. (2019). ANALISIS KEMAMPUAN KOMUNIKASI MATEMATIS SISWA SMP PADA MATERI SEGIEMPAT DAN SEGITIGA. Jurnal Kajian Pembelajaran Matematika, 3(April), 18-23.

Sulistyani, D., \& Roza, Y. (2020). Hubungan Kemandirian Belajar dengan Kemampuan Pemecahan Masalah Matematis. Jurnal Pendidikan Matematika, 11(1), 1-12.

Wakit, A., \& Hadapiningradja, R. (2018). ANALYSIS OF MATHEMATICAL PROBLEMSOLVING SKILLS AND STUDENT PROCESS SKILLS IN PROBLEM-BASED LEARNING Abstrak. ANARGYA: Jurnal Ilmiah Pendidikan Matematika, 1(2). 